\title{
Practice of Personal Hygiene among Rural women of a Selected Community in Bangladesh
}

\author{
K S Imtiaz ${ }^{1}$, K Begum² ${ }^{2}$ N Begum ${ }^{3}$, S Naureen ${ }^{4}$, J Barua ${ }^{5}$, J Faruque ${ }^{6}$, A R Khalid ${ }^{7}$
}

1 Dr. Khondker Saif Imtiaz MBBS (DU), MPH (DU), DPS (DU), PGDDM (DU) Assistant Professor Dept. of Community Medicine International Medical College, Gazipur

2 Prof. Dr. Khadiza Begum MBBS (DU), DPH (DU), MPH (UK), PhD (BD) Professor \& Ex- Head Dept. of Community Medicine Ad-din Women's Medical College, Dhaka

3 Prof. Dr. Nilufar Begum MBBS (DU), M Phil (Micro), WHO Fellow (Bangkok, Delhi Professor \& Head

Dept. of Microbiology

Bangladesh Medical College, Dhaka

${ }^{4}$ Dr. Samiha Naureen

MBBS (DMC)

Honorary Medical Officer

Dept. of Medicine

Dhaka Medical College Hospital, Dhaka

5 Jony Barua

BSN (DU), MPH (SUB)

Lecturer

Dept. of Nursing Research \& Education International Nursing College, Gazipur

${ }^{6}$ Dr. Jobaer Faruque

BDS (DU), MPH (AIUB)

Honorary Medical Officer

Dept. of Dental Surgery

BIRDEM, Shahbag, Dhaka

${ }^{7}$ Dr. Abdur Rahman Khalid

MBBS (CU)

Lecturer (Ex)

Dept. of Pharmacology

Ad-din Women's Medical College, Dhaka

\section{Correspondence}

Dr. Khondker Saif Imtiaz

Assistant Professor

Dept. of Community Medicine

International Medical College, Gazipur.

E mail: saifimtaz105@yahoo.com

\section{Abstract}

Background : Good health is a marker of good economic status of a nation. Personal hygiene should be maintained first for obtaining great accuracy in work, low suffering from diseases and to reduce possibility of diseases.

Objective : This study was undertaken to assess practice of personal hygiene among rural women of a selected community in Bangladesh.

Materials \& Methods : A descriptive type of cross sectional study was conducted during March-June 2012. 150 women of various ages selected from Garibpur and Tangurpur villages of Jessore District to assess two basic components of personal hygiene, hand washing and safe drinking water. Non probability convenient sampling technique was followed and data were collected by face to face interview using pre tested, self administered, semi structured questionnaire.

Results : The mean age of the respondents was 33 years. Regarding educational qualification, $87.33 \%$ were educated in different levels and $12.67 \%$ were illiterate. Occupational status revealed majority $(74.67 \%)$ of them were housewives. Regarding economic condition, most $(60 \%)$ of the respondents had family income $<10,000$ Taka. In this study, majority $(87.34 \%)$ had practiced hand washing before eating. Among them on taking different types of food (86.26\%) practiced hand washing before taking meals only $13.74 \%$ before taking breakfast and none of the respondents washed hands before taking any dry food. Majority (95.34\%) practiced hand washing after defecation, among them (82\%) used soap, $16 \%$ used ash and $2 \%$ used soil after defecation. In this study, majority (90.67\%) used tube well which was not marked red, $6 \%$ used pond and $3.33 \%$ used river as their source of drinking water.

Conclusion : Good practice of personal hygiene and use of safe drinking water has significant importance to lead a healthy life, the villagers of Bangladesh should be well motivated regarding this aspect by regular health education programmes.

Key words : Personal hygiene, Hand washing practice, Safe drinking water.

\section{Introduction}

The word "Hygiene" is derived from Hygeia, the goddess of health in Greek mythology. Hygiene is defined as "The science of health and embraces all factors which contribute to healthful living."1 The term personal hygiene includes all those factors, which influence the health and wellbeing of an individual which comprises a broad range of day to day activities such as bathing, clothing, hand washing, toilet, care of nails, feet $\&$ teeth, spitting, coughing, sneezing, personal appearance, inculcation of clean habits along with drinking safe water. Some regular hygiene practices may be considered good habits by a society while neglect of hygiene can be considered as a source of various diseases threatening to health. To reduce the exposure to all the diseases and conditions spreads through unclean hands, we have to develop the habit of good personal hygiene such as washing of hands before taking food and after defecation. A survey report revealed that overall $54 \%$ of world's population maintains good personal hygiene, which is higher among women (59.5\%) than men (44.5\%). ${ }^{2}$ According to World Health Organization ${ }^{3}, 1.8$ million people die every year from diarrhoeal diseases including cholera; $90 \%$ are children under 5 years of ages, mostly in developing countries. Of diarrhoeal diseases, $88 \%$ is attributed to unsafe water supply, inadequate sanitation and hygiene.

Among all hygiene practices, the basic and first step is hand washing and hand hygiene is central in preventing spread of infectious diseases in home and everyday life settings. ${ }^{4}$ An average of $65 \%$ of death caused by diarrheal diseases could be reduced if good hygiene practice accompanies the provision of water and sanitation. ${ }^{5}$ Diarrheal disease has been considered as a serious global problem ${ }^{6}$ and leading cause of child mortality around the world. ${ }^{7}$ Around 2.4 million deaths could be prevented annually by good hygiene practice, reliable sanitation and drinking water. $^{8}$ Evidence showed that hand washing can reduce the occurrence of diarrheal diseases by $14-$ $40 \%{ }^{9}$ Different studies showed that hand washing can decontaminate hands and prevent crosstransmission. ${ }^{10}$ Hand washing with soap can also reduce the risk of endemic diarrhea and skin infections. ${ }^{11}$ Recent research ${ }^{12}$ also suggests that hand washing is an important preventive measure to reduce the incidence of acute respiratory tract infection also. The effectiveness of hand washing with soap can reduce diarrheal risk up to $47 \% .{ }^{13}$ Hand washing is best done with soap and enough water for rinsing. However if soap is not available or affordable, clear mud or ashes are also preferable. Use safe drinking water is another important part of good and healthier life. To reduce water borne diseases, safe water should be used for drinking, cooking and all other domestic needs. Now a days, access to safe drinking water is $85.2 \% .{ }^{14}$ Through many research ${ }^{15}$ it is well established that only hand washing and drinking safe water can reduce $82 \%$ risk of food and 
water borne diseases. By practicing good personal hygiene people would be able to lead a healthy life.

\section{Methodology}

The study was a descriptive type of cross sectional study conducted during March-J une 2012 to assess two basic components of personal hygiene, hand washing and safe drinking water. 150 women of various age groups ranging from 18-45 years residing in two selected villages, namely Garibpur and Tangurpur of Chougasa Upazilla of J essore district were selected for the study. Non probability convenient sampling technique was followed. A pre-tested semi structured questionnaire was used for face to face data collection, which contained 18 questions regarding socieo-demographic, hand washing and safe drinking water status of the respondents. After collection data were checked, verified, compiled and analyzed by using SPSS software.

\section{Results}

Socio demographic character showed that majority $75(50 \%)$ of the respondents ws $>30$ years of age, $38(25.33 \%)$ belonged to between $26-30$ years of age and only $13(8.67 \%)$ was $<20$ years of age. The mean age of the respondents was 33 years. Among 150 respondents, majority $56(37.33 \%)$ completed primary education, 39(26\%) secondary education, 32(21.33\%) higher secondary education, $4(2.67 \%)$ were graduate and $19(12.67 \%)$ were illiterate. Majority $112(74.67 \%)$ of the respondents was housewife followed by $14(9.33 \%)$ was involved in business, $11(7.33 \%)$ was service holder and $13(8.67 \%)$ was involved with other profession.

Table I : Socio demographic status of respondents (no. 150)

$\begin{array}{ccc}\text { Age (Years) of respondent } & \text { Frequency } & \text { Percentage (\%) } \\ 20 & 13 & 8.67 \\ 21-25 & 24 & 16.00 \\ 26-30 & 38 & 25.33 \\ >30 & 75 & 50.00 \\ \text { ducational Qualification } & & \\ \text { Illiterate } & 19 & 12.67 \\ \text { Primary } & 56 & 37.33 \\ \text { Secondary } & 39 & 26.00 \\ \text { HSC } & 32 & 21.33 \\ \text { Graduate } & 4 & 2.67 \\ \text { Housewife } & & \\ \text { Service } & 112 & 74.67 \\ \text { Business } & 11 & 7.33 \\ \text { Others } & 14 & 9.33 \\ \text { Occupation } & 13 & 8.67\end{array}$

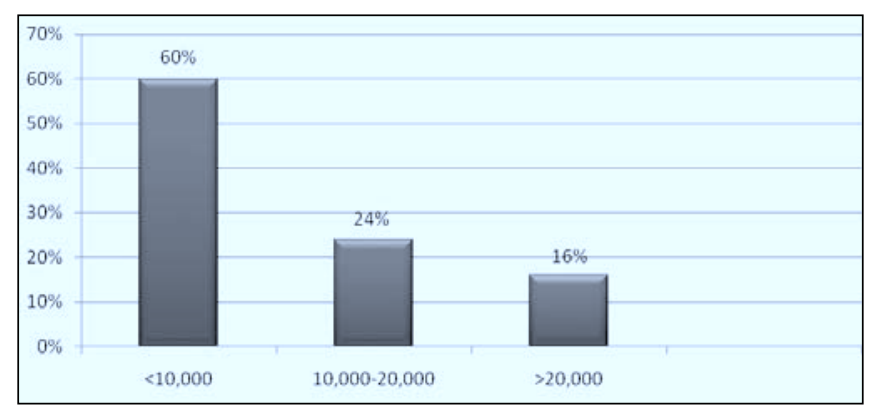

Figure 1: Distribution of respondents according to monthly family income (In taka)
In the Figure 1, most 90 (60\%) of the respondents had less than 10,000 taka monthly family income, 36(24\%) had between 10,000 20,000 taka and only $24(16 \%)$ had more than 20,000 taka.

\section{Table II : Hand washing practice of respondents before eating}

$\begin{array}{ccc}\text { Hand washing practice before eating } & \text { Frequency } & \text { Percentage (\%) } \\ \text { Yes } & 131 & 87.34 \\ \text { No } & 19 & 12.66 \\ \text { Total } & 150 & 100\end{array}$

In the Table II, among 150 respondents majority $131(87.34 \%)$ practiced hand washing before eating, while $19(12.66 \%)$ do not had practice regarding this matter.

\section{Table III : Hand washing practice of respondents before taking different types of food}

Hand washing practice before taking different types of food Frequency Percentage (\%)

$\begin{array}{ccc}\text { Meal } & 113 & 86.26 \\ \text { Breakfast } & 18 & 13.74 \\ \text { Dry food } & 0 & 0 \\ \text { Total } & 131 & 100\end{array}$

Table III showed, majority $113(86.26 \%)$ of the respondents practiced hand washing before taking meal and 18(13.74\%) before taking breakfast. In this study, no respondents practiced hand washing before taking dry food.

\section{Table IV : Hand washing practice of respondents after defecation}

$\begin{array}{ccc}\text { Hand washing practice after defecation } & \text { Frequency } & \text { Percentage (\%) } \\ \text { Yes } & 143 & 95.34 \\ \text { No } & 7 & 4.66 \\ \text { Total } & 150 & 100\end{array}$

As shown in the Table IV, among 150 respondents most 143 (95.34\%) practiced hand washing after defecation, while $7(4.66 \%)$ did not practice.

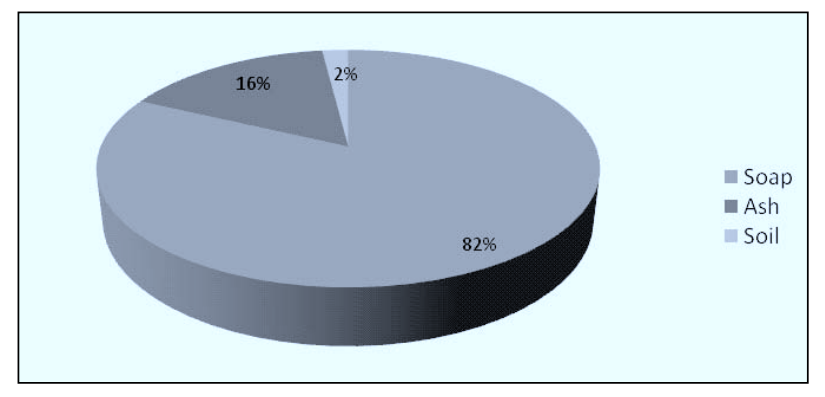

Figure 2 : Distribution of respondents according to using different types of hand washes after defection

As shown in the Figure 2, among 143 respondents who practiced hand washing after defecation, majority $118(82 \%)$ of the respondents used soap, $23(16 \%)$ used ash and $9(2 \%)$ used soil after defecation.

\section{Table V : Source of drinking water of respondents}

$\begin{array}{ccc}\begin{array}{c}\text { Source of drinking water } \\ \text { Tube well }\end{array} & \text { Frequency } & \text { Percentage (\%) } \\ \text { (not marked red) } & 136 & 90.67 \\ \text { Pond } & 9 & 6.00 \\ \text { River } & 5 & 3.33 \\ \text { Total } & 150 & 100\end{array}$


As shown in the Table $\mathrm{V}$, among 150 respondents, majority 136 $(90.67 \%)$ used tube well (not marked red), 9(6\%) used pond and $5(3.33 \%)$ used river as their source of drinking water.

\section{Discussion}

In this study, out of 150 respondents majority $75(50 \%)$ of the respondents was $>30$ years of age, The mean age of the respondents was 33 years. Regarding educational qualification, majority $(87.33 \%)$ of the respondents were educated in different levels and only 19(12.67\%) were illiterate. Majority $112(74.67 \%)$ of the respondents was housewife. Economic status revealed that $90(60 \%)$ of the respondents had less than 10,000 taka monthly family income, 36(24\%) had between $10,000-20,000$ taka and only $24(16 \%)$ had more than 20,000 taka. It showed the overall socioeconomic condition of the respondents was better than most of the rural people of Bangladesh.

The study showed that, among 150 respondents majority 131(87.34\%) practiced hand washing before eating, while $19(12.66 \%)$ did not practice. Among those who practiced hand washing before eating, majority $113(86.26 \%)$ of them practiced hand washing before taking meal and $18(13.74 \%)$ before taking breakfast $\&$ no respondents practiced hand washing before taking dry food. In this study, most 143 $(95.34 \%)$ practiced hand washing after defecation, while $7(4.66 \%)$ do not had practice regarding this matter. Among those who practiced hand washing after defecation, majority $118(82 \%)$ of them used soap, $23(16 \%)$ used ash and $9(2 \%)$ used soil after defecation. With the same objective, ICDDR,B regularly conduct survey regarding hand washing practice in rural areas of Bangladesh. A study ${ }^{16}$ done among villagers of randomly selected 100 villages from 36 districts in rural Bangladesh showed that, $14 \%$ of respondents washed both hands with soap after defecation. Less than $1 \%$ used soap \& water for hand washing before eating and/or feeding a child. More commonly people washed their hands only with water, $23 \%$ after defecation \& $5 \%$ before eating. A minority of respondents washed their hands with soap after defecation. This is the actual scenario of majority villagers of Bangladesh. But as our study was done with 150 respondents of better socioeconomic condition, the study result did not reflect the actual scenario about hand washing practice of rural people of Bangladesh.

In this study, it was showed that among 150 respondents, majority 136 $(90.67 \%)$ used tube well, 9(6\%) used pond and 5(3.33\%) used river as their source of drinking water. A bulletin report ${ }^{17}$ revealed that, tube well water is used primarily as a source of drinking water by the vast majority (90\%) of rural people in Bangladesh. So this report is similar with the result of our study regarding source of drinking water. In this study no tube well was found arsenic contaminated (marking with red colour). Although at present prevalence of arsenic in drinking water had been identified in 61 out of 64 districts of Bangladesh (except hilly districts) and degree of contamination varies from $1 \%$ to over $90 \%$ with an average contamination of $29 \%$. As arsenic contamination in drinking water is a major issue in Bangladesh, tube wells should be regularly examined and the villagers must be aware about this concern.

\section{Conclusion}

From study result and discussion it is concluded that practice of personal hygiene in relation to hand washing before meal was satisfactory but during eating snacks and other dry foods, the practice of hand washing was very poor. Women were conscious about washing after defecation and used soap mostly. There is no alternative of good personal hygiene practice for leading a healthy life. Therefore, the people of should be well motivated regarding practices of good personal hygiene by regular health education programmes.

\section{References}

1. Park K. Park's Textbook of Preventive $\&$ Social Medicine. $21^{\text {st }}$ Edition. Jabalpur,M/s Banarsidas Bhanot, 2011:43

2. Lubys, Agobatwalla M, Feikin DR, Painter J, Billhimmer W, Atref A, Hoekstar RM. Effect of hand washing in child health. Lancet.2005;366:225-33

3. Brace J, Boschi-Pinto C, Black RE.WHO estimates of causes of death in children.Lancet.2005; 365:1147-52

4. Bloomfield, SF, Aiello AE, Cookson B, O'Boyle C, Larson, EL, The effectiveness of hand hygiene procedures including hand-washing and alcohol-based hand sanitizers in reducing the risks of infections in home and community settings" American Journal of Infection Control 2007;35, suppl 1:S1-64

5. Water Aid. Hygiene. 2009. Retrieved from http:// www.wateraid.org/uk/ what we do/the need/5901.asp

6. WHO Health Statistics. Mortality and burden of diseases. Geneva, Switzerland: WHO; 2008

7. Boschi-Pinto C, Velebit L, Shibuya K. Estimating child mortality due to diarrhea in developing countries. Bull World Health Organ. 2008; 86:710-717.

8. Prüss-Üstün A, Bos R, Gore F, Bartram J. Safer water, better health: costs, benefits and sustainability of intervention to protect and promote health. Geneva: World Health Organization; 2008

9. Hoque BA. Hand washing practices and challenges in Bangladesh. Int J Environ Heal R. 2003; 13(1):81-87.

10. Kaltenthaler E, Waterman R, Cross P. Faecal indicator bacteria on the hands and the effectiveness of hand-washing in Zimbabwe. J Trop Med Hygiene 1991. 1991; 94(5):358-63.

11. Bartram J, Cairncross S. Hygiene, Sanitation and Water: Forgotten foundations of Health. PLoS Med.2010; 7(11):1000367

12. Reiff F, Roses M, Venezell, Quick R V. Low cost safe water for the world: a practicle interium solution health policy. Lancet. 2005; 456-470

13. Curtis V, Cairncross $S$. Effect of washing hands with soap on diarrhoea risk in the community: a systematic review. Lancet Infectious Diseases. 2003; 3(5):275-81.

14. Herber G. Simple methods for the treatment of drinking water and better health. J ournal of progress on sanitation \& drinking water; 102(2):189-93

15. Ashbolt $\mathrm{N} \mathrm{J}$. Microbial contamination of drinking water and disease outcomes in developing regions. Journal of water and health; 3:229-238

16. Halder A K. Observed hand cleanliness and other measures of hand washing behavior in rural Bangladesh.2010; 10(545):1186

17. Nahar N. Arsenic: Silent catastrophe. Bulletin of Environmental Health.1997; 1:1-4 